\title{
La prensa española ante el IV Centenario de la publicación de la primera parte del Quijote (2005)
}

\author{
M. ángeles Chaparro Domínguez*
}

En el año 2005 se cumplieron 400 años de la publicación de la primera parte de El ingenioso hidalgo Don Quijote de la Mancha, de Miguel de Cervantes. Esta efemérides no pasó inadvertida a la sociedad gracias a las diferentes actividades organizadas por diversos organismos oficiales, asociaciones y artistas de todos los campos, de las que se hicieron eco los medios de comunicación de masas. Este trabajo, precisamente, quiere estudiar cómo vivieron estos medios aquel aniversario, en concreto, cómo cubrieron los principales diarios españoles dicha conmemoración.

Analizaremos los periódicos de tirada general más importantes (El País, El Mundo, ABC, La Vanguardia y La Voz de Galicia), con el fin de poder extraer conclusiones de gran calado ${ }^{1}$. Hemos estudiado las informaciones de todo tipo que publicaron estos diarios desde enero de 2004 hasta diciembre de 2005. Hemos escogido este periodo de dos años para comprobar si ya en 2004 la prensa fue preparando a la sociedad para la efemérides que llegaría en unos pocos meses. En cuanto a las informaciones, hemos analizado todos los géneros periodísticos: noticia, reportaje, crónica, entrevista, columna de opinión y editorial.

A pesar de haber consultado todas las noticias, en el estudio de cada medio solo incluiremos las informaciones que hemos considerado de mayor relevancia ya que, de lo contrario, nos encontraríamos ante un análisis repleto de ruido que sólo estorbaría la llegada de conclusiones.

* Universidad Complutense de Madrid.

1. Este estudio forma parte de un análisis más amplio que incluye diferentes diarios provinciales (Deia, La Tribuna de Ciudad Real, Levante-El Mercantil Valenciano, Córdoba y el periódico digital La Crónica de Guadalajara). Las conclusiones del estudio de estos cinco diarios son similares a las que incluimos al final de este artículo. 


\section{EL PAÍS}

En el diario El País ${ }^{2}$, fundado el 4 de mayo de 1976, la noticia es el género informativo predominante para dar cobertura al IV Centenario del Quijote. Encontramos textos que recogen las actividades celebradas en toda España y en distintos países latinoamericanos. La mayoría de las noticias aparecen firmadas, no pertenecen a ninguna agencia, lo que es un ejemplo de la importancia que concedió el diario a la efemérides.

Además de noticias, encontramos once reportajes, una crónica informativa y una entrevista. La temática de los reportajes es heterogénea: los actos que está preparando el Ejecutivo para celebrar el IV Centenario; las principales ediciones publicadas de la obra; un recorrido muy breve, con cinco paradas, por la Ruta del Quijote, las primeras ediciones del Quijote en España e Inglaterra, las universidades de verano que celebraron cursos sobre la famosa novela, etcétera.

La crónica pertenece al escritor Arcadi Espada, que realiza una valoración del libro La resurrección de Don Quijote, publicado en el III Centenario de la obra y que se volvió a reeditar en 2005. La entrevista tiene como protagonista al ex-presidente de Colombia y escritor, Belisario Betancur, en noviembre de 2004. Betancur considera que los consejos del hidalgo «son sabios de increíble vigencia» (El Pais, 18/11/2004).

En las informaciones encontramos posturas enfrentadas. Por un lado, tenemos a José María Ridao y Francisco Rico, que se muestran muy críticos con las celebraciones de la efemérides, y por otro, sin tener en cuenta las opiniones de los autoridades que promueven los eventos, encontramos a la historiadora Carmen Iglesias, que aplaude los eventos organizados.

El diplomático, ensayista y embajador de España ante la UNESCO, José María Ridao, explicó en su intervención en las jornadas Cervantes y la edad conflictiva, celebradas en Sevilla en abril de 2005, que la forma de abordar el IV Centenario del Quijote adolece de los mismos errores cometidos en el III Centenario: «En ambos casos fueron proyectos gubernamentales que pretendieron arrancar la respuesta de qué significa el Quijote a los lectores». Para Ridao, los poderes públicos no deben meterse en la interpretación de la obra, pues no existe una única lectura de la misma. El escritor fue más lejos y alertó sobre los peligros que, desde su punto de vista, conllevaba la implicación de los gobiernos en la reivindicación de hechos culturales. «No se aleja de lo que hizo Milosevic en Yugoslavia» (El País, 03/04/2005), advirtió acerca de la posible deriva de estas políticas a tesis nacionalistas, una opinión quizá algo exagerada, pues la ideología de Slobodan Milosevic provocó la muerte de miles de personas en los Balcanes.

El cervantista Francisco Rico, por su parte, en la presentación de su última edición de la novela en octubre de 2004, señaló que, ante la multitud de

2. Es el diario líder indiscutible de información general, con una tirada media de 563.495 ejemplares y un promedio de difusión de 431.033 periódicos, según datos de la OJD de enero a diciembre de 2008. 
actos de todo tipo que se avecinaban en el siguiente año, confiaba en que la sociedad no se confundiera y tuviera claro que «el Quijote es una novela, no un centenario» (El País, 19/10/2004).

La académica Carmen Iglesias, en cambio, animaba a festejar «sin miedo y sin complejos de inferioridad, sin dejar que la obra esconda al autor» el IV Centenario de la publicación de la primera parte de la novela. «Igual que pasa en los grandes países culturales, no hay que temer en absoluto al exceso de conmemoraciones» (El País, 08/02/2005). Iglesias hizo estas declaraciones en un ciclo de conferencias celebrado el 8 de febrero de 2005 en la Fundación Lázaro Galdiano de Madrid titulado La España de Cervantes.

Por otro lado, El País recoge que PRISA se convierte en uno de los patrocinadores oficiales de la efemérides, es decir, llegó a un acuerdo con la comisión organizadora del IV Centenario, presidida por José Manuel Blecua, por el que se comprometía a promocionar la celebración a través de sus diferentes medios de comunicación.

El País presta atención al tema del feminismo en la obra. El diario recoge la presentación del libro El Quijote en clave de mujeres, en el que la profesora de la Universidad Complutense de Madrid y escritora Fanny Rubio recopila contribuciones de distintos expertos - como la doctora Iris Zabala, la especialista en el siglo XVIII Juana Vázquez, el medievalista José Luis Lorenzo o la catedrática de la Universidad Autónoma de Madrid Carmen Ruiz- acerca de los diferentes personajes femeninos que aparecen en la novela. Según Rubio, Cervantes se adelantó a su tiempo al tratar con sumo respeto a las mujeres que aparecen en su novela más universal ${ }^{3}$.

El Quijote es un gineceo y eso hay que decirlo. Cervantes fue el primer feminista, se adelantó a la Ilustración en el campo de las mujeres. Cuando escribe de ellas Cervantes se pone serio y habla con respeto. A las putas las llama mis grandes señoras y a las niñas, mis doncellas. (El País, $30 / 05 / 2005)$

\section{Artículos de opinión}

El País es uno de los medios analizados que más textos de opinión recoge relativos al IV Centenario, con un total de 25 artículos. Entre ellos se encuentran cinco cartas de los lectores, la mayoría quejándose por algún aspecto

3. El estudio de los personajes femeninos del Quijote y de la valoración de la mujer en la obra de Cervantes no es ninguna novedad del IV Centenario: cuenta con larga tradición. A título de ejemplo puede verse, sobre los personajes, Las mujeres del Quijote (Wiltrout, 1973). Para el estudio sociológico de la mujer representada en la novela, Amor, sexo y aventura en las mujeres del Quijote (Falcón, 1997). Lógicamente, la fecha del centenario incrementa la bibliografía sobre los puntos recurrentes en toda la investigación humanística de comienzos del XXI, la ideología de género, la cual afecta a todas las áreas de estudio. M. ${ }^{a}$ del Carmen Marín Pina ha estudiado a la lectora femenina en trabajos como $\mathrm{La}$ aventura de leer y las mujeres del Quijote (2005). 
relacionado con las celebraciones. Aparecen, además, varios artículos que se posicionan a favor o en contra de los fastos del IV Centenario. Están a favor el escritor Andrés Trapiello y el propio periódico, que escribe un editorial sobre este tema.

Andrés Trapiello, un colaborador habitual de La Vanguardia, que en 2005 publicó dos libros cervantinos (Las vidas de Miguel de Cervantes: una biografía distinta, Destino y Al morir don Quijote, Destino), escribe un artículo a finales de 2004 donde explica que, aunque quizá estén celebrándose actos inútiles, es necesario quedarse más bien con los eventos positivos porque consiguen mantener vivo el espíritu de la novela en la sociedad.

Es probable que suframos este año no pocas acometidas deleznables a
cuenta del dichoso centenario, y puede incluso que muchas de ellas no
favorezcan la lectura de sus libros, pero no me cabe la menor duda de
que en medio de todo ello hallaremos obras y manifestaciones de gran
valor que contribuirán a mantener vivo el legado espiritual del Quijote
entre aquellos que nunca lo han leído y que nunca lo van a leer. [...]
Lleguen, pues, centenarios y conmemoraciones; caigan ediciones del
Quijote, buenas, malas, eruditas y populares, de lujo y de quiosco. [...]
Es preferible, sí, un millón mal gastado en Cervantes y en don Quijote
que un solo euro en la guerra de Irak, por poner un ejemplo. (El País,
Tribuna, 27/12/2004)

La última afirmación del escritor, poniendo al mismo nivel la Guerra de Irak y el IV Centenario, resulta, cuanto menos, oportunista. Trapiello, además, anima a la sociedad a que lea el libro, independientemente de su nivel de estudios, y a que saque sus propias conclusiones, sin dejarse convencer por eruditos que consideran que la novela no es apta para todos los públicos.

El editorial de El País del 2 de enero de 2005 también es partidario de las celebraciones quijotescas.

La multitud de celebraciones, en el peor de los casos, puede llegar a la saturación ciudadana por exceso, y en el mejor y más probable, servirá para la difusión de una obra ejemplar. [...] Celebremos, pues, con alborozo los jóvenes y vitales primeros 400 años de la novela sobre un ingenioso hidalgo que enloqueció de tanto añorar un mundo perdido. (El País, Editorial, 02/01/2005)

Haciendo gala de su imparcialidad, el diario recoge cuatro columnas de opinión que se muestran contrarias a los fastos del IV Centenario. La primera de ellas pertenece al escritor, profesor de la UNED y traductor, Manuel Lloris, que opina justo lo contrario que Trapiello.

Si algún libro hay con fácil apariencia y dificilísima digestión es éste, Don Quijote de la Mancha. De ahí que su lectura sea únicamente apta para individuos nacidos con la literatura metida en los huesos [...]. Nos diluirán el festejo con tantas celebraciones y encima oiremos una sarta de disparates 
paridos por el acuciante imperativo de la originalidad. Fatigarán al personal y conseguirán que una efeméride merecidísima acabe oliendo a propaganda incluso con acento político. (El País, Tribuna, 14/01/2005)

Tenemos después al escritor y profesor de instituto Luis Manuel Ruiz, que considera que los festejos sólo provocarán la huida de los lectores de la novela.

Mucho me temo que el dichoso aniversario que masifica librerías y bibliotecas ha de servir, más que para rescatar ese pájaro prisionero, para hundirlo debajo de nuevas capas de yeso y parafina. Palabras estruendosas como clásico, cumbre, inmortalidad no hacen más que aturdir al lector potencial y obligarle a escurrirse por la puerta de atrás, que el deseo de liberarse de esa avalancha de mármol que se le viene encima. Digámoslo sin ambages: el Quijote es, primero y ante todo, una broma [...]. Pero por una retorcida ironía del destino, esa levedad acabó convirtiéndose en roca maciza y ahora es esta antología de chistes y situaciones disparatadas la que se respeta como una sutil radiografía de las miserias humanas, etcétera. (El País, 10/03/2005)

Margarita Rivière, periodista y ensayista, por su parte, se queja de que absolutamente toda España se haya subido al carro del IV Centenario del Quijote por la única razón de estar en la vanguardia de la moda.

He escuchado a feministas, a banqueros, a curas, a inspectores de Hacien$\mathrm{da}$, a representantes de ONG, incluso a ¡nacionalistas catalanes! haciendo reverencias al héroe de la triste figura. Toca. Y todo el mundo lo sabe. [...] Creo que esta conmemoración tan exitosa es la expresión perfecta del poder supremo del papanatismo contemporáneo: más homogeneidad, imposible. (El Pais, 20/03/2005)

Encontramos otros artículos interesantes que no entran en la valoración de la efemérides. Es el caso de la escritora y catedrática de Literatura Española en la Universidad Autónoma de Barcelona Carme Riera, que habla de cómo celebró Cataluña el III Centenario del Quijote en 1905. Riera explica que, por aquel entonces, la novela se utilizaba desde Madrid como un símbolo nacionalista, tras el desastre del 98, lo que provocaba la ira de los grupos catalanistas más radicales.

Así las cosas, el tercer centenario de la publicación de la primera parte del Quijote tendría una trascendencia también diferente en tierras catalanas, ya que detrás del debate de la conveniencia de que Cataluña se sumara o no a la celebración, latía el enfrentamiento Cataluña-España. [...] Sin embargo, tanto los partidarios de la conmemoración como sus detractores acabaron por contribuir a ella, ya que toda la prensa catalana, incluso la más revolucionaria, dedica en 1905 números extraordinarios, algunos de una gran belleza, al libro cervantino. (El País, Tribuna, $23 / 04 / 2004)$ 
Aparece también un texto interesante del periodista y ensayista Eduardo Haro Tecglen, que considera que el poder se ha apropiado del Quijote, pese a que Cervantes siempre fue un ácrata.

Es curioso que el poder se haya apoderado, por fin, del Quijote; una obra de trasgresión, hecha por quien se había vuelto ácrata antes de la palabra [...]. Ahora el poder ha aprendido y exalta al ácrata antiguo. Le basta gastar unos millones y se hace culto, libre, inteligente. (El País, Tribuna, 22/12/2004)

Mención especial merece el artículo escrito por José Saramago. El Premio Nobel de Literatura apunta de forma magistral que la locura del ingenioso hidalgo fue un modo de que Alonso de Quijano alcanzase la ansiada libertad.

\begin{abstract}
Imaginemos durante un momento, al menos durante un momento, que don Quijote no está loco, que simplemente finge una locura. De ser así, no tuvo otro remedio que obligarse a cometer las acciones más disparatadas que le pasasen por la mente para que los demás no alimentaran ninguna duda acerca de su estado de alineación mental. [...] Fue en virtud de esa genial simulación de Cervantes cómo el bueno de Alonso de Quijano, convertido en don Quijote, consiguió abrir la cuarta puerta, la que todavía le estaba faltando, la puerta de la libertad. La curiosidad lo empujó a leer, la lectura le hizo imaginar, y ahora, libre de las ataduras de la costumbre y de la rutina, ya puede recorrer los caminos del mundo. (El País, Tribuna, 22/05/2005)
\end{abstract}

La tesis que defiende Saramago acerca de la fingida locura de Alonso de Quijano ha sido recogida y explicada en detalle en diferentes obras ${ }^{4}$.

Como vemos, el diario recoge numerosos artículos de opinión de gran calidad, cada uno con aportaciones diferentes, donde observamos un auténtico debate intelectual. Entre los columnistas, destacan escritores de prestigio como Francisco Ayala, José Saramago, García Montero, Andrés Trapiello o Carme Riera y críticos o eruditos como Francisco Rico o Harold Bloom.

\title{
EL MUNDO
}

Como ocurre en El País, la noticia es el género informativo predilecto de El Mundo ${ }^{5}$, fundado el 23 de octubre de 1989, para cubrir las actividades del IV Centenario del Quijote. En líneas generales, podemos afirmar que la cobertura de la efemérides es más que aceptable, pues aglutina la mayoría de

4. Por ejemplo, «En torno a Cardenio en el Quijote: Locura, suerte y honor» (Satake, 1986) o «Don Quijote: una dialéctica entre la cordura y la locura» (Encinar, 1989). Otro tópico remozado y nutrido bibliográficamente en torno a las fechas del centenario es precisamente este de la pluriforme significación de la locura quijotesca: «La razón crítica de Cervantes y la locura de Don Quijote» (Betto, 2005) o «La locura de Don Quijote» (Goytisolo, 2005).

5. La tirada media del diario es de 427.306 ejemplares, mientras que su promedio de difusión se sitúa en 323.587 diarios, según datos de la OJD de enero a diciembre de 2008. 
los principales actos celebrado en el país, aunque es cierto que puede pecar de centralista, porque aparecen numerosos eventos celebrados en Madrid. El diario recoge también actividades celebradas en diferentes países de América del Sur y Europa. Además, incluye dos entrevistas «reportajeadas», una del bailaor Rafael Amargo y otra al por aquel entonces director del Instituto Cervantes, César Antonio Molina. En la primera, Amargo presenta su espectáculo futurista en Madrid (DQ. Pasajero en Tránsito) y en la segunda, Molina, a la pregunta del periodista sobre qué le está pareciendo la celebración del IV Centenario, responde: «Muy acorde para explicar lo que españoles e hispanoamericanos somos hoy en el mundo y lo que queremos ser» (El Mundo, Cultura, 20/01/2005).

Podemos afirmar que El Mundo se implicó de forma notable en el centenario, hasta el punto de llegar a convertirse en uno de los patrocinadores oficiales de la efemérides a través de su empresa editora, Unidad Editorial, lo que se tradujo en que tanto el diario como otras revistas del grupo dieron cobertura y publicidad a las celebraciones.

En el terreno político, el diario se muestra moderadamente crítico con el presidente del Gobierno, José Luis Rodríguez Zapatero, por no haber acudido a la presentación de los actos organizados por el Ejecutivo el 20 de diciembre de 2004 para celebrar la efemérides. Asimismo, recoge opiniones de fuentes del Partido Popular que explican que Zapatero no fue a dicho evento porque no le importaba la celebración y porque se dio cuenta de que los actos no estaban a la altura de lo que él prometió durante la campaña electoral.

El académico y cervantista Francisco Rico fue uno de los eruditos que más dio que hablar en el IV Centenario de la obra. Rico, que rechazó capitanear la comisión organizadora de los actos del cuarto centenario por incompatibilidad laboral —ya que iba a publicar dos reediciones del Quijote —, se convierte en una de las personalidades más críticas con las celebraciones.

\footnotetext{
Ni don Quijote representa el ser de España ni se saca nada dándole vueltas a si está loco o cuerdo... Lo peor que puede ocurrir es que el centenario consagre aún más los tópicos, que la gente prefiera los símbolos y las ideas prefabricadas a pasar bonísimos ratos leyendo el libro y sacando sus propias conclusiones. (El Mundo, Cultura, 04/10/2004)
}

Hay que evitar la dispersión [...]. Corremos peligro de saturación, hay que elegir lo mejor y andarse con ojo para no cansar. (El Mundo, Cultura, 21/12/2004)

Independientemente de lo que piense Rico, el Quijote, a lo largo de sus 400 años de historia, se ha convertido en un símbolo del país, de nuestra historia, además de ser un icono textual.

Rico no fue el único que se mostró crítico con las actividades organizadas para conmemorar el IV Centenario. El catedrático de Literatura española de la Universidad de Castilla-La Mancha, Joaquín González Cuenca, denunció en la presentación de dos libros relacionados con el Quijote, que «sobran el 
$80 \%$ de los actos y falta descubrir que el Quijote es un libro» (El Mundo, Cultura, 03/01/2005).

El escritor Juan Manuel de Prada, por su parte, se mostró preocupado por el tratamiento otorgado a la obra en las distintas actividades conmemorativas. «Me da miedo que se trivialice demasiado la obra de Cervantes, que se la acabe considerando como una especie de queso manchego» (El Mundo, Cultura, 21/01/2005), indicó De Prada en la presentación de tres antologías cervantinas.

Volviendo a Francisco Rico, el académico explicó, en un congreso internacional quijotesco celebrado en Valladolid los días 19, 20 y 21 de enero titulado El nacimiento del Quijote, que «no se puede convertir al Quijote en un símbolo castizo. Es empequeñecerlo» (El Mundo, Cultura, 22/01/2005). Además de Rico, son muchos los intelectuales, cervantistas, escritores e historiadores que relacionan, desde distintos puntos de vista, el Quijote con el nacionalismo. El historiador Ricardo García Cárcel, por ejemplo, señaló en el mismo congreso de Valladolid que «la épica de don Quijote nunca fue nacional», lo que explica que se identifiquen con la obra las personas «que no han querido alinearse como nacionalistas, ni han estado de acuerdo con la España nacional católica, ni con la liberal, vertical, horizontal, centralista o plural», que «representan a una tercera España alternativa» a la tradicional polarización de las dos Españas (El Mundo, Cultura, 20/01/2005).

En esas mismas jornadas, el hispanista y cervantista francés Jean Canavaggio ${ }^{6}$ lamentó «el enfrentamiento entre comunidades autónomas en torno a la celebración del IV Centenario» y «la ausencia de un proyecto conmemorativo común». «Es evidente que la celebración obedece a un deseo político, del presidente Zapatero, y que se quiere hacer del Quijote el aglutinante de una España unida, pero sería lamentable que algunas comunidades consideraran a Cervantes como de una cultura distinta» (El Mundo, Cultura, 20/01/2005).

La escritora catalana Carme Riera, por su parte, señaló en la presentación de su libro El Quijote desde el nacionalismo catalán, en torno al Tercer Centenario que transcurridos cien años, la recepción catalana de la obra es mucho más favorable, porque "ahora los clásicos se leen como literatura y ya no se politizan» (El Mundo, Cultura, 15/02/2005). De nuevo en Cataluña, el que fuera presidente de la Generalitat en 2004, Pascual Maragall, explicó que Cataluña se estaba involucrando de forma notable en los actos del cuarto centenario porque «su aspiración es que el día en que celebremos un aniversario relevante del Tirant lo Blanc, las instituciones culturales del Estado se impliquen tanto en la celebración como lo estamos haciendo nosotros en Cataluña» (El Mundo, Catalunya, 22/04/2005) con la obra de Cervantes.

6. Canavaggio, además de autor de una de las biografías fundamentales de Cervantes, ha dirigido la edición de las Obras Completas para la famosa editorial Gallimard de París y ha editado varias de las piezas teatrales de Cervantes, como Los baños de Argel (1984) y sus Entremeses (1988). Recientemente ha publicado un valioso estudio de literatura comparada, Don Quijote, del libro al mito (2006). 
El periodista Antonio Lucas es una de las claves de la cobertura de la efemérides por parte de El Mundo ya que fue el encargado de realizar la Ruta del Quijote en pleno mes de julio de 2005, y escribió, como ya hiciera Azorín hace 100 años en el diario El Imparcial $7^{7}$, crónicas de viaje de todo lo que vieron sus ojos. En sus artículos se mezclan descripciones de los campos, los pueblos y las gentes de La Mancha con pasajes del Quijote ambientados en los lugares por donde pasea Lucas. El hecho de que el periodista hable con los habitantes de los municipios de la zona aporta un toque de humanidad a los textos. Así, por ejemplo, Lucas reproduce el testimonio de «el viejo Manuel», de Villacañas, quien cuestiona la popularidad de la Ruta del Quijote.

Eso de la Ruta del Quijote es un invento de los políticos. Ya verán, van a estar solos por los caminos; dos turistas aquí, dos turistas allí. Ná. Aquí, menos Quijote y más agua. (El Mundo, Uve, 12/07/2005)

Son crónicas con un toque literario, repletas de metáforas, que tratan de reproducir en nuestra mente imágenes de los paisajes por los que anduvo don Quijote con su fiel escudero.

\begin{abstract}
Adelante por los caminos, ya hacia Ossa de Montiel, de nuevo los campos como una antorcha tumbada, minados de alpacas de espiga seca. Es de nuevo el paisaje que suplica una sombra sin decirlo. Allí donde cruzan bajo la carretera esqueletos de ríos que aguardan el gotero de un trasvase por el que unos y otros, norte y sur, le han puestos a las cosechadoras lanzagranadas a un costado. (El Mundo, Uve, 12/07/2005)
\end{abstract}

\title{
Artículos de opinión
}

El Mundo realiza una notable valoración del IV Centenario del Quijote a través de múltiples artículos de opinión escritos por columnistas de distintos campos (periodistas, escritores, intelectuales, etc.). En 2004 encontramos dos textos y en 2005, un total de dieciséis, lo que suma dieciocho artículos de opinión.

El primer artículo lo escribe el escritor, ensayista y catedrático de Literatura española en la Universidad Complutense de Madrid, Santos Sanz Villanueva. En él aplaude que se vayan a celebrar numerosas actividades de toda índole para conmemorar el IV Centenario, pero echa de menos un debate, una reflexión sobre la vigencia o no del Quijote hoy.

A falta del debate que diga por qué y para qué es hoy necesario don Alonso de Quijano, se anuncian acumulativamente actividades en una especie de totum revolutum que provoca desconfianza. [...] Lo que amenaza es una exhibición más aparente que sustanciosa. (El Mundo, Cultura, 04/10/2004)

7. Las crónicas de Azorín de 1905 fueron recogidas ese mismo año en el libro La ruta del Quijote, que volvió a ser editado en 2005 . 
Además, se queja de que no se vayan a crear obras intelectuales relacionadas con el Quijote, tal y como se hizo en el III Centenario, y alerta sobre el riesgo de que tanto fasto produzca hartazgo y rechazo.

José Luis López-Bulla inaugura el año 2005 con una columna en la que anima a Cataluña en general y a Barcelona en particular a que festejen el IV Centenario del Quijote por las alabanzas que hizo Cervantes en su obra universal a la ciudad condal.

No me estoy refiriendo a una conmemoración de carácter institucional sino a un acontecimiento verdaderamente popular [...]. Lo cierto es que sería un disparate que se pasara de puntillas con estúpido disimulo o que, de manera explícita, se dijera que eso no va con nosotros. [...] Sugiero con el mayor respeto y la más encendida pasión que la señora Caterina Mieras, la combativa Consellera de Cultura, haga suya esta propuesta. (El Mundo, Catalunya, 03/01/2005)

Encontramos un editorial que ensalza los valores del Quijote, principalmente porque ese día el suplemento del diario (El Cultural) dedicaba su número al ingenioso hidalgo y a la relación de la obra con disciplinas artísticas tan divergentes como el cine, la ópera o la pintura abstracta. Nos resulta emotivo el final del artículo.

Y esa es, en cierto modo, la lección última del Quijote: la dignidad de un ser humano que sale en pos de sus sueños sin resignarse a envejecer en una vida mediocre y que regresa desvencijado a casa, corneado por el mundo pero «vencedor de sí mismo». (El Mundo, Opinión, 06/01/2005)

El director de El Mundo, Pedro J. Ramírez, escribe un extenso artículo de opinión criticando la política antiterrorista del presidente del Gobierno, José Luis Rodríguez Zapatero, y utiliza el IV Centenario del Quijote como otro motivo más de ataque.

Ahora es el presidente quien debe demostrar que cuando nos sorprendió a todos prometiendo en su debut como líder de la oposición que se implicaría al máximo en el cuarto centenario del Quijote - luego sólo lo ha hecho a medias - , aquello no era sólo una pose intelectual fraguada en la lectura de Borges, sino que respondía al entendimiento de lo que significaba España en esos albores del siglo XVII. (El Mundo, Opinión, 09/01/2005)

José Jiménez, filósofo y profesor de Estética y teoría de las Artes en la Universidad Autónoma de Madrid, publica una letal columna contra de la celebración del Centenario del Quijote y de cualquier centenario artístico. El columnista cree que en estas actividades se esconde un profundo sentimiento de culpa por años de abandono y una exaltación política y comercial ligada a los efectos más perjudiciales de la cultura de masas.

En mi opinión, la mejor contribución a este centenario de la publicación de la primera parte de don Quijote sería justo lo contrario de este ruido invasor, 
el silencio del respeto. Propongo un ejercicio de ascetismo, que dejemos a la gente en paz, que políticos, intelectuales y artistas callemos sobre don Quijote, y que para celebrar su sentido como literatura de nuestro tiempo, leamos y comentemos, por ejemplo, la poesía de Cervantes y el Persiles. Para acabar de una vez por todas con los centenarios. Y celebrar la vida de la literatura y las artes. (El Mundo, Cultura, 13/01/2005)

En el extremo opuesto encontramos al escritor Luis Antonio de Villena, quien, diez días más tarde que Jiménez escribe un artículo donde se muestra defensor a ultranza de los centenarios, como fórmula para rescatar a los autores y a las obras del olvido.

Bien medidos y gestionados, los centenarios son toques de atención, y perchas (en lenguaje periodístico) que sirven para revitalizar autores en el arte que sea. El centenario del Quijote (casi una labor de Estado) se diría innecesario pero no es cierto. Incluso al Quijote y a Cervantes - lo estamos viendo- les viene bien el timbrazo de la centuria. (El Mundo, Cultura, 26/01/2005)

La tribuna de opinión más emotiva publicada por El Mundo pertenece a Eleuterio Sánchez, un popular delincuente de los años 60 que fue detenido en 1964 por robar una joyería y estuvo encarcelado 18 años. A Sánchez le entristece que se hable tanto del Quijote y se conozca tan poco de su autor.

La efeméride de tu criatura es la que este año festejamos. ¿Y la tuya, qué? ¿Quién se acuerda de la fecha de tu nacimiento? [...] El desconocimiento del gran público sobre lo que fue tu penosa existencia resulta tan paradójico respecto a tu colosal obra que me incita y mueve a escribirte, en tono personal, esta carta. (El Mundo, Opinión, 18/05/2005)

En otro artículo, el popular escritor Francisco Umbral defiende la maestría, el estilo y el valor de los textos de Miguel de Cervantes, aunque este hiciera plagios.

Pues naturalmente que el ingenioso hidalgo o el propio Cervantes tiene cosas de los clásicos, de los griegos e incluso de sus compañeros generacionales [...]. Pero habría que hacer aquí una defensa del plagio como obra de arte, incluso como obra maestra, que es lo que es en algunos libros [...]. La cultura es continuidad y quien en la continuidad sólo ve plagio es que no sabe leer ni escribir. [...] Cervantes tiene un estilo propio, que es todo lo que necesita un escritor. Borges supo verlo y resumirlo. ¿Borges plagiario? Pues también. (El Mundo, Última, 21/05/2005)

La última columna de opinión relativa al IV Centenario es del 28 de mayo y pertenece al escritor Antonio Gala. El escritor cree que el libro tuvo un éxito inmediato porque era un espejo de la decadencia española y «el melancólico 
sólo puede sonreír ante sí mismo». Además, considera que es un libro del que se pueden aprender conocimientos para el futuro.

Hubo y hay que leer el Quijote para aprender el futuro. Representa un claro escarmiento. De ahí que sea un clásico. (El Mundo, Opinión, 28/05/2005)

Como hemos visto, cada artículo pertenece a un autor diferente y apenas se repite la temática de los mismos, aunque si tuviéramos que sacar una idea predominante, esta sería el hartazgo por los miles de actos insustanciales organizados para conmemorar el centenario. Pensamos que son artículos interesantes, en líneas generales, y nos preguntamos por qué El Mundo decidió dejar de valorar el centenario en mayo de 2005, cuando todavía quedaban siete meses para que concluyese la celebración del evento. Echamos de menos artículos de opinión en ese periodo final, donde sí que se podrían valorar con propiedad los fastos de la efemérides y su repercusión y acogida en la sociedad.

\section{$A B C$}

Como ocurre en otros diarios, la noticia es el género informativo predominante en $A B C^{8}$, diario fundado en 1891, para dar cobertura a las actividades del IV Centenario del Quijote. Sin embargo, a diferencia de otros medios, en este diario encontramos numerosas entrevistas, ocho en total a escritores relacionados con el texto, así como crónicas y reportajes que aportan valor añadido a la información.

Entre los entrevistados destaca el académico y cervantista Francisco Rico. El escritor, el 25 de mayo de 2004, aplaude la implicación del Gobierno en la celebración de la efemérides para lograr objetivos mayores como elaborar programas de incitación a la lectura y hacer llegar los clásicos tanto a jóvenes como a lectores sin estudios filológicos o históricos.

El presidente de la comisión del IV Centenario del Quijote y catedrático de Literatura Española de la Universidad Autónoma de Barcelona, José Manuel Blecua, es entrevistado por $A B C$ el 15 de noviembre de 2004. Resulta paradójico que en toda la entrevista ni el periodista ni él mencionen la efemérides que va a tener lugar en poco más de un mes. En lugar de esto, Blecua diserta sobre la importancia de la obra y de su autor.

Encontramos otra entrevista al filólogo Francisco Márquez Villanueva, profesor de la Universidad de Harvard y recurrente estudioso de Cervantes ${ }^{9}$. Es uno de los pocos entrevistados que opina sobre las celebraciones del

8. La tirada media de $A B C$, según datos de la OJD de enero a diciembre de 2008 , es de 343.525 ejemplares, mientras que su promedio de difusión se sitúa en 251.642 diarios.

9. Fuentes literarias cervantinas (1973), «La buenaventura de Preciosa» (1985-1986), «Cervantes y el erotismo estudiantil» (1991). 
IV Centenario. En su caso, se muestra crítico con el origen de los actos y con la ausencia de obras teatrales cervantinas.

\begin{abstract}
$\mathrm{Su}$ inspiración es oficialista y hubiera sido más deseable que hubiera partido de abajo a arriba y no viceversa, aunque se está haciendo un buen esfuerzo. Me parece penoso que no se haya incluido el teatro cervantino, que apenas se está representando. Y también echo de menos el cervantismo. Desde mediados del siglo XX se ha dado un gran hervidero de ideas sobre Cervantes y creo que hubiera sido un buen momento para ponerlas en orden. $(A B C, 16 / 06 / 2005)$
\end{abstract}

Villanueva considera, además, que los niños deben leer el libro en el colegio, como lo hicieron grandes escritores como Balzac o Dickens. Además, cree que toda gran novela parte del Quijote.

En cuanto a temática, dejando a un lado las diversas actividades organizadas para conmemorar la efemérides, uno de los asuntos más relevantes a los que presta atención $A B C$ es el nacionalismo y su relación con la novela. En concreto, encontramos cuatro informaciones que responden a esta cuestión. La primera de ellas, del 19 de febrero de 2004, recoge unas declaraciones del por aquel entonces vicepresidente de Castilla-La Mancha, José María Barreda, donde afirma que el Quijote es «la insignia de nuestra patria común e indivisible. Es como la expresión del artículo 2 de la Constitución Española, es una patria histórica, simbólica y real a la vez, porque en esta obra nos vemos reflejados todos, no sólo los españoles sino todos los hispanos» (ABC, 19/02/2004).

En la siguiente noticia, Carme Riera participa en un debate organizado en el Fórum de Barcelona donde se trata el tema del Quijote y el nacionalismo. La escritora confía en que en 2005 se abandonen las «tonterías casticistas y nacionalistas para sacar mayor provecho de la obra de Cervantes» ( $A B C$, 19/06/2004). Ricardo García Cárcel, profesor de la Universidad Autónoma de Barcelona y colaborador de $A B C$, es otro de los eruditos que se refiere al nacionalismo en el Quijote. En un congreso celebrado en Valladolid en enero de 2005, Cárcel considera que Miguel de Cervantes tuvo conciencia intelectual de España-nación sobre el eje de la memoria histórica común de los españoles. Así, don Quijote provoca en Cervantes «un profundo sentimiento de España, de la que Cervantes tuvo una conciencia intelectual y sentimental como nación pero, al mismo tiempo, de una nación plural y diversa» $(A B C$, 20/01/2005). Meses después, Cárcel escribirá un profundo y denso artículo de opinión en este diario donde corrobora la tesis nacionalista defendida en este congreso.

Por último, encontramos otra aportación de la escritora Carme Riera. En la presentación de su libro El Quijote desde el nacionalismo catalán, en torno al Tercer Centenario, la escritora reitera que «el Quijote ya no es un libro para la utilización política o nacionalista, y me parece estupendo que se vea como literatura, que es lo que es» $(A B C, 15 / 02 / 2005)$. 
En cuanto a las actividades que cubre el diario, al ser un medio generalista recoge eventos celebrados por todo el país, aunque presta especial interés a los organizados en Castilla-La Mancha, Madrid y Barcelona. También detalla algunos actos de la Comunidad Valenciana y de Andalucía, y deja fuera a otras comunidades como el País Vasco y Galicia.

En el terreno político, $A B C$ se muestra muy crítico con la ausencia del Presidente del Gobierno, José Luis Rodríguez Zapatero, el 20 de diciembre de 2004 en la presentación de los actos del IV Centenario. Además de publicar dos artículos de opinión al respecto al día siguiente, el día antes de la presentación escribía una noticia para censurar la ausencia de Zapatero.

\begin{abstract}
Bastante sorpresa ha causado esta ausencia porque el presidente no sólo azotó a Aznar desde la oposición, allá por 2001, por no tener claro cómo celebrar el IV Centenario de la obra maestra de Cervantes, sino que, estando en campaña electoral, el pasado febrero, sí acudió a la presentación de los proyectos del PSOE a este respecto. (ABC, 19/12/2004)
\end{abstract}

Además, $A B C$ da voz al Partido Popular en este asunto, que apunta que Zapatero no fue a la presentación de un programa «mediocre y efímero» porque «sus consejeros le han dicho que el programa no tiene suficiente entidad $\mathrm{y}$ le han recomendado que no vaya» ${ }^{10}$.

Además de las críticas del Partido Popular de las celebraciones, $A B C$ recoge también la opinión negativa al respecto del anterior presidente de la Sociedad Estatal de Conmemoraciones Culturales (SECC), el historiador Luis Miguel Enciso, que opina que buena parte del programa que se va a llevar adelante durante el centenario ya se había puesto en marcha antes.

\begin{abstract}
Se han cambiado los títulos de algunas exposiciones y actos culturales; en algún caso se ha sustituido al comisario y se han desechado proyectos que tenían relevancia, como «El Quijote y la Revolución Científica», «El Quijote y el Derecho», «El Quijote y la Prensa», «A las riberas del Pisuerga. El nacimiento del Quijote» o «El esplendor de la decoración en tiempos del Quijote», por citar sólo unos pocos ejemplos. (ABC, 21/12/2004)
\end{abstract}

Por otro lado, resulta interesante y elogiable que el diario regale ya en 2004 la universal novela en dos tomos, patrocinados por la Junta de Castilla-La Mancha. A cambio, el periódico publica dos publirreportajes especiales sobre la Ruta del Quijote y la comunidad manchega. Pocos meses después, $A B C$ venderá por 99 euros una edición de lujo de la obra ilustrada por el famoso grabador francés del siglo XIX Gustave Doré.

10. Son declaraciones de Beatriz Rodríguez-Salmones, portavoz del PP en la Comisión de Cultura del Congreso. $A B C, 20$ de diciembre de 2004. 


\section{Artículos de opinión}

El diario $A B C$, de todos los estudiados, es el que más artículos de opinión relacionados con el Quijote y su IV Centenario incluye. En concreto, recoge un total de veintisiete artículos, la mayoría de ellos columnas de opinión, aunque también encontramos alguna carta al director de los lectores. Lo que nos sorprende es que no hayan incluido ningún editorial $\mathrm{y}$, sobre todo, que no hayan recogido un artículo valorativo en los últimos meses de 2005, en el que hacer balance de lo que ha significado la efemérides.

Entre todos los articulistas sobresalen cuatro ya que han escrito más de una columna relativa al centenario de la obra: J. H. Ponos, con cuatro colaboraciones, Enrique Badosa, que escribe en tres ocasiones, y José Rosell Villasevil e Ignacio Ruiz Quintano, con dos columnas de opinión cada uno.

En su primer artículo, del 20 de junio de 2004, el articulista J. H. Ponos compara a Castilla-La Mancha con el espíritu del Quijote por ser la única comunidad que da el agua de sus ríos a las demás sin quejarse. En su siguiente columna, del 9 de enero de 2005, Ponos alaba que El Corte Inglés se haya convertido en patrocinador oficial del centenario pues este hecho conlleva que el logotipo de la efemérides se incluya en todos los folletos y publicidades de los grandes almacenes, lo que ayudará a difundir la estela del Quijote. Once días más tarde, Ponos critica con dureza que la Ruta del Quijote vaya a beneficiar a municipios de la provincia de Ciudad Real en detrimento de Toledo y otras comarcas. Por último, el articulista, que siempre escribe desde Toledo, aplaude, el 13 de marzo de 2005, que, gracias a la Junta de Comunidades, se estén representando por toda Castilla-La Mancha diferentes obras de Cervantes.

Enrique Badosa, escritor y traductor al castellano de diferentes obras catalanas, escribe una columna el 19 de enero de 2005 en la que declara confiar en que el IV Centenario promueva la lectura del Quijote. Además, considera que en los próximos meses la efemérides va a ser muy festejada en Barcelona.

La vinculación de lo cervantino con Barcelona es algo que debiera ser bien conocido y bien celebrado. Todo indica que mucho se va a hacer en este sentido. [...] Con estas lecturas Barcelona ha de afirmar o descubrir y agradecer su cervantismo. (ABC, Opinión, 19/01/2005)

En el siguiente artículo, del 17 de agosto de 2005, Badosa recomienda leer el libro por su hilaridad, tanto en 2005 como en cualquier momento. En su última colaboración, el articulista considera que Barcelona ha celebrado de un modo adecuado la efemérides ya que le debe mucho a Cervantes.

Además de notables actos públicos, también aquí «El Quijote» está siendo uno de los libros que más - ¡muchísimo! — se venden en las librerías. Se diría que de una vez por todas la Ciudad Condal es agradecida a Cervantes. (ABC, Opinión, 19/12/2005) 
El presidente de la Sociedad Cervantina de Esquivias y miembro de la Real Academia de Bellas Artes y Ciencias Históricas de Toledo, José Rosell Villasevil, el 26 de enero de 2004, realiza una crítica de una adaptación del Quijote de la compañía valenciana Lóm Imprebis y aplaude que el director haya representado a Dulcinea en el arpegio de un violín. En su segunda y última colaboración, del 30 de enero de 2005, el escritor divaga sobre cómo cree que fue la espada del ingenioso hidalgo, aprovechando que una empresa toledana ha lanzado al mercado este nuevo souvenir.

Ignacio Ruiz Quintano, por su parte, es el último articulista que publica más de una columna en relación al Quijote. En sus dos artículos, uno del 29 de septiembre de 2004 y otro del 3 de diciembre de 2004, el columnista y ensayista utiliza un tono jocoso y erudito para criticar la edición popular del Quijote de la Real Academia de la Lengua y, en el artículo posterior, al presidente del Gobierno.

La Academia presentó el miércoles el Quijote del centenario, que, en contra de lo que podía esperarse, ha resultado un Quijote bastante menos humilde que el presidente Rodríguez, cuya deslumbrante greguería parlamentaria - «A humilde no me gana nadie»— ya ha dado la vuelta al mundo. ( $A B C$, Opinión, 03/12/2004)

Por otro lado, encontramos varios artículos de opinión donde los articulistas se muestran críticos con José Luis Rodríguez Zapatero por distintos motivos. El primero de ellos pertenece al periodista, novelista y poeta satírico Jaime Campmany, quien, el 2 de septiembre de 2004, critica a Zapatero y a la por aquel entonces ministra de Cultura, Carmen Calvo, tomando como excusa las celebraciones del IV Centenario. César Alonso de los Ríos, periodista y ensayista, por su parte, se muestra implacable con el presidente del Gobierno. Considera que no tiene sentido que el Gobierno se involucre en el Centenario cuando no siente los colores del país, algo que también les sucede a la mayoría de los pensadores e intelectuales.

Llaman los gobernantes a una celebración del aniversario del Quijote. Malo. Me temo que saldrá poco, por no decir nada. [...] ¿Cómo va a moverse la creatividad ante el que Unamuno llamó «el libro de España» si a la mayoría de los pensadores e intelectuales les quema la noción de España? [...] Por otra parte, ¿puede concebirse un gobernante menos quijotesco y menos caballeresco que este llamado José Luis Rodríguez Zapatero? [...] De hecho él y sus socios entienden las naciones como ínsulas baratarias, que las quieren dadas, regaladas. ( $A B C$, Opinión, 09/12/2004)

Por todo ello, De los Ríos opina que, a diferencia de lo que ocurrió en 1905, en 2005 no aparecerán trabajos de investigación serios relativos al Quijote.

La ausencia de Zapatero en la presentación del programa de actos promovidos por el Gobierno el 20 de diciembre de 2004 fue el tema de dos artículos publicados al día siguiente contra el presidente. En el primero de ellos, el 
articulista Tulio Demicheli, en tono de guasa, relativiza todas las actividades anunciadas por la ministra de Cultura, Carmen Calvo, y pone en duda la importancia de los actos que impidieron acudir a Zapatero al acto. El segundo pertenece a Fernando R. Lafuente, profesor de Literatura hispanoamericana en la Universidad Complutense de Madrid, que, con el mismo tono jocoso que su compañero, critica la ausencia del Presidente.

Como en la vieja canción de Sabina, ayer en lo del Quijote estaban todos menos tú. Y el tú resultó ser el presidente del Gobierno, Rodríguez Zapatero. [...] Lástima que el gran descubridor del Quijote para la actual cultura española no pudiera asistir por problemas de agenda. Lástima de agenda. Se esperaba su presencia por su insistencia en el asunto. [...] Sin embargo, una mera reunión de la ejecutiva - mira que no tendrán ejecutivas a lo largo del año— obligó a suspender. ( $A B C$, Opinión, 21/12/2004)

$A B C$ recoge críticas positivas, como la de Elías, del 21 de octubre de 2004, donde alaba la campaña publicitaria y mediática de la Junta de Castilla-La Mancha para anunciar el IV Centenario por su modernidad (el cartel principal, que aparece en la portada de este trabajo, incluye, por ejemplo, modernos molinos de viento que generan energía eólica) y por hacer apetecible viajar a la región.

Como vemos, son textos completamente heterogéneos, con una temática diversa, estilos diferentes y redactados por diferentes profesionales. Aún así podemos extraer algunas conclusiones generales como son las críticas al presidente del Gobierno, José Luis Rodríguez Zapatero, y el tema recurrente del nacionalismo en la obra.

\section{LA VANGUARDIA}

A pesar del importante papel que juega Barcelona en la última parte del Quijote, ni la ciudad ni La Vanguardia se volcaron en la celebración del IV Centenario de la obra. El periódico ${ }^{11}$, fundado el 1 de febrero de 1981, sólo publica una veintena de informaciones entre 2004 y 2005 referidas a este hecho. Resulta curioso que La Vanguardia no recoja dos de las más importantes exposiciones de la ciudad condal: Visiones del Quijote, en la Pedrera, con pinturas de Doré, Hogarth, Picasso, Dalí o Saura, y El Quijote y el mar, en el Museo Marítimo.

Destaca la noticia como género informativo predominante. Las actividades que recoge son mayoritariamente de Barcelona, no aparecen otras ciudades ni municipios catalanes. En lo referente a otras comunidades, solo encontramos reseñada una actividad de Madrid, el estreno de la obra del grupo catalán Els

11. La tirada media del diario barcelonés es de 238.004 ejemplares, con un promedio de difusión de 201.859, según datos de la OJD (entre enero y diciembre de 2008). 
Joglars En un lugar de Manhattan. En el montaje, el director del grupo, Albert Boadella recrea varios pasajes de la novela, como la acogida del hidalgo por parte de los duques o el duelo en la playa de la Barceloneta con el Caballero de la Blanca Luna ${ }^{12}$. Como destaca la crítica, en esta pieza Boadella alumbra un Quijote castellano y un Sancho catalán, siendo completamente respetuoso con el texto cervantino.

Por otro lado, resulta interesante un artículo en el que el presidente de ERC, Josep Lluís Carod-Rovira, se lamenta del poco apoyo que se está brindando al centenario de la novela Solitud de Víctor Català ${ }^{13}$ en comparación con los actos del Quijote, a lo que el presidente de la Generalitat, Pascual Maragall responde:

Nuestra aspiración es que el día que celebremos un aniversario relevante de Tirant lo Blanc, las instituciones culturales del Estado se impliquen tanto como lo hemos hecho nosotros en Catalunya en el cuarto centenario del Quijote. (La Vanguardia, Suplemento, 22/04/2005)

Vemos, por tanto, que lo que menos importa a Maragall es el valor literario o histórico de la obra. Las celebraciones en Cataluña son completamente interesadas.

El diario concede bastante importancia en varias de sus informaciones al cervantista barcelonés Francisco Rico, quien en un primer momento acepta conducir la comisión organizadora de los actos del IV Centenario pero luego renuncia por incompatibilidad laboral.

Además de noticias, encontramos dos crónicas, una de ellas muy interesante, donde el periodista hace un resumen de lo que fue el III Centenario del Quijote en toda España (las actividades que se llevaron a cabo, las conferencias que se impartieron, los libros que originó y cuál fue el origen del evento).

Asimismo, La Vanguardia incluye dos entrevistas interesantes sobre el IV Centenario aunque en la primera de ellas, la efemérides pasa de puntillas por la conversación entre el periodista y el entrevistado. Se trata del escritor Rafael Sánchez Ferlosio, quien el 3 de diciembre de 2004 recibe la noticia de que le han galardonado con el premio Cervantes. El periodista aprovecha la ocasión para preguntarle por el IV Centenario del Quijote, a lo que el escritor contesta:

Nunca he entendido el por qué de la obsesión en el cinco o en el cero del sistema efemeridiano, por qué no celebrar el veintisiete aniversario en vez de privilegiar al cero o, no digamos, los dos ceros. (La Vanguardia, Suplemento, 03/12/2004)

12. 〈http://www.elsjoglars.com/cast/Espectaculos/manhattanprensa.htm〉.

13. Víctor Català (1869-1966) fue el seudónimo utilizado por Caterina Albert y Paradis para sus novelas. No es necesario añadir que la comparación entre el Quijote y Solitud establecida por Carod está fuera de toda proporción razonable. 
Ferlosio también le deja claro al periodista que en su discurso de agradecimiento por el premio no hablará sobre el Quijote.

La siguiente entrevista, el 2 de enero de 2005, se dedica por completo al IV Centenario de la obra pues el entrevistado es José Manuel Blecua, presidente del comité ejecutivo del IV Centenario del Quijote. En ella, Blecua explica que el evento es un proyecto de Estado dirigido fundamentalmente a los jóvenes y que su objetivo es crear proyectos permanentes, por lo que las ayudas e incentivos fiscales continuarán a lo largo de 2006. En cuanto a la importancia de las otras lenguas del país diferentes al castellano, Blecua responde lo siguiente:

Queremos que el IV Centenario sea el año del respeto a las otras lenguas. Precisamente por ser un proyecto de Estado debe ser capaz de integrar a todas las lenguas del Estado. Vamos a vivir, ver y leer «El Quijote» en castellano, en catalán, en euskera, en gallego..., algo que estoy seguro de que va a generar un espíritu de convivencia y respeto mutuo. (La Vanguardia, Suplemento, 02/01/2005)

De hecho, en 2005 se reeditó la novela en catalán y en euskera. En el primer caso, se volvió a publicar Don Quixot de la Mancha (Barcelona, Edicions 62), traducido en 1930 por Antoni Bulbena i Tussell. A la presentación de la reedición en euskera de Don Kijote Mantxa 'ko, traducida en 1977 por el sacerdote Pedro Berrondo, acudió la ministra de Cultura, Carmen Calvo. En gallego, solo encontramos la traducción de 1992 de Valentín Arias López, titulada $O$ enxeñoso hidalgo Don Quixote da Mancha (Xuntanza-Boreal).

El escritor Andrés Trapiello, acompañado por el fotógrafo Juan Manuel Castro Prieto, se embarca en la Ruta del Quijote, por un encargo del Magazine de La Vanguardia, para ver qué queda de La Mancha que atravesó el famoso hidalgo.

Trapiello queda completamente enamorado de la zona: de la austeridad y la dureza de su paisaje, el silencio de sus pueblos, el carácter huraño de sus gentes, los colores del campo, etcétera.

La Mancha tiene el color del infinito. La Mancha es, se la mire desde donde se la mire, en cualquier estación del año, a cualquier hora del día, bellísima. Sobrepone y admira. (Magazine, 07/11/2004, 60)

El reportaje puede ser considerado una crónica de viajes, muy descriptiva, cuya conclusión podría ser que, aunque han cambiado muchas cosas en la zona desde que nació el Quijote, la esencia que describe el libro continúa completamente intacta.

Puerto Lápice, El Toboso, Consuegra, Herencia, Argamasilla de Alba y Quintanar de la Orden son algunos de los pueblos que visitan fotógrafo y escritor siguiendo los pasos del Quijote. Las fotografías del reportaje siguen el tono del texto e intentan materializar conceptos abstractos como el silencio, el 
infinito y la nada, sensaciones que le evoca a Trapiello La Mancha. También encontramos costumbrismo en el texto, teñido de gris.

En La Mancha el tiempo tiene una dimensión diferente a la que tiene en cualquier parte. Aquí el tiempo pasa para nadie. Al fin vemos por una calle a un ser humano. Es una mujer de negro, de luto riguroso, con vestido negro, medias negras, zapatos negros y paraguas negro. Está lloviendo. Cuando llueve en La Mancha a La Mancha se le pone rostro de Viernes Santo y un cielo color calvario. La mujer es vieja. Camina con dificultad. Nos ha visto y recela. (Magazine, 07/11/2004, 58)

\section{Artículos de opinión}

La Vanguardia publica tan sólo cuatro artículos de opinión relacionados con el Quijote y su IV Centenario. El primero de ellos pertenece a Carlos Sentís. En él, el periodista considera que el libro, a diferencia de lo que ocurrió cien años atrás, no ha sufrido ningún rechazo por parte de la ciudad de Barcelona.

El aludido rechazo no creo que exista en parte alguna en nuestros días, aunque el Quijote, por poco leído, sea un gran desconocido. La parte final sucede en Barcelona, ciudad tan querida por Cervantes. (La Vanguardia, Opinión, 25/06/2004)

Sentís realiza un recorrido por el Quijote y recoge los halagos que brinda el hidalgo a la ciudad de Barcelona.

El siguiente artículo de opinión lo escribe el 12 de enero de 2005 el escritor catalán Oriol Pi de Cabanyes y más que al Quijote, rinde homenaje al cervantista mallorquín Josep María Casasayas (fallecido en 2004), que dedicó su vida a traducir el libro al mallorquín ${ }^{14}$.

Baltasar Porcel, escritor, periodista y crítico literario, se encarga de escribir otra columna de opinión el 1 de mayo de 2005. En ella habla de una conferencia celebrada en el Ateneu, en un tono irónico, y del sentimiento catalanista que posee Barcelona. En esa misma línea, realiza la siguiente afirmación, completamente exagerada.

Sin embargo, España existe, sobre todo en Catalunya, donde celebramos con más entusiasmo que nadie en toda la Hispanidad el IV Centenario del Quijote. (La Vanguardia, Opinión, 01/05/2005)

Por último, encontramos un artículo del escritor y periodista Xavier Bru de Sala el 20 de julio de 2005, donde habla sobre el respeto y la admiración

14. Fue el impulsor de la Asociación de Cervantistas cuya andadura comienza en 1991 con el primero de sus grandes congresos internacionales, celebrado en Almagro, y posteriormente Nápoles (1994), Menorca (1997), Lepanto (2000) y Lisboa (2003). Además promovió la celebración de los Coloquios de la Asociación de Cervantistas, reunidos en Alcalá de Henares, Montilla, Argamasilla, El Toboso, Villanueva de los Infantes, Oviedo, Roma y Seúl. 
que sienten los escritores catalanes por la literatura castellana y cómo esa relación no se produce a la inversa. Así, el columnista utiliza la celebración del IV Centenario del Quijote en Barcelona para demostrar que los catalanes sí que aplauden la cultura castellana.

En el presente, ¿hay que recordar que es en Barcelona donde más y mejor se celebra el centenario del Quijote? (La Vanguardia, Suplemento, 20/07/2005)

Se equivoca el columnista, como ya le pasó a Baltasar Porcel. Reiteramos que no es cierto que Barcelona fuera la ciudad más implicada en las celebraciones del IV Centenario del Quijote. Tuvo varias exposiciones interesantes pero poco más que resaltar.

\section{LA VOZ DE GALICIA}

La Voz de Galicia ${ }^{15}$, fundado el 4 de enero de 1882, como viene siendo habitual en el resto de diarios, utiliza la noticia como género informativo predominante para recoger las actividades celebradas con motivo del IV Centenario. El periódico realiza una cobertura excelente de los actos menores (de municipios, asociaciones, bibliotecas, colegios e institutos), los más numerosos en la comunidad. Parece ser que las grandes ciudades gallegas pasaron de puntillas por el Centenario, con muy pocas actividades, quizá porque Galicia no aparece ni una sola vez en la novela de Cervantes.

Además de las actividades celebradas en la comunidad, La Voz de Galicia recoge también actos reseñables de otras ciudades españolas, como Madrid, Barcelona y las capitales manchegas, o extranjeras, como París, aunque los de estas últimas en menor medida. La mayoría de las noticias que se refieren a Galicia aparecen firmadas, mientras que el resto se atribuyen a las agencias informativas.

Uno de los mejores aciertos del diario es la entrevista que realiza a comienzos de 2005 a José Manuel Blecua, presidente de la comisión del IV Centenario. Blecua cree que los actos que han organizado no son excesivos y se marca como gran meta que la obra cale en los jóvenes.

- ¿Corremos el riesgo de acabar hasta el yelmo de don Quijote con el año que se nos viene encima?

- Creo que no. Creo que es homenaje suficiente a Cervantes lo que se está haciendo desde todos los niveles administrativos y académicos. Comunidades Autónomas, ayuntamientos, universidades, fundaciones, ateneos... Hasta los lugares más humildes han hecho un gran esfuerzo por homenajear a don Miguel. Es un buen principio que promete un buen final.

15. El diario, el primero de Galicia, presenta un promedio de difusión de 120.086 ejemplares, con una tirada media de 102.858 diarios, de enero a diciembre de 2008, según datos de la OJD. 
— ¿Qué le haría sentirse pagado cuando en 12 meses haga balance?

- Que la meditación sobre el libro, sobre la lectura y la escritura, sea de provecho sobre todo para los jóvenes. (La Voz de Galicia, Cultura y TV, 08/01/2005)

Encontramos, además, dos crónicas, ambas referidas a iniciativas de algunos presos de la comunidad, y un reportaje a comienzos de 2005, sobre una escultura quijotesca en el municipio de Laxe (La Coruña).

Por otro lado, a pesar de la ingente cantidad de noticias que aparecen relativas al IV Centenario, que pueden dar a entender que el diario se involucra con la efemérides, $\mathrm{La}$ Voz de Galicia no publicó ningún monográfico ni especial al respecto, ni crónicas sobre la Ruta del Quijote, ni tampoco vendió o regaló la magna novela de Cervantes. Se limitó a contar cómo lo estaba celebrando su comunidad.

Una de las noticias más interesantes que recoge el diario trata sobre unas conferencias cervantinas celebradas en Nueva York a comienzos de 2005, donde varios catedráticos alertan sobre las interpretaciones tópicas e ideologizadas de la obra. Antonio Regalado, catedrático de la Universidad de Nueva York, señaló lo siguiente:

Está surgiendo un Cervantes que podría ser miembro de Izquierda Unida o de Amnistía Internacional. (La Voz de Galicia, 06/03/2005)

Los hispanistas reconocen que las conmemoraciones propician que surjan enfoques y puntos de vista diversos y polémicos, pero en ocasiones, los planteamientos ideológicos priman sobre los estéticos o estrictamente literarios, lo que afecta a la seriedad del análisis.

En cuanto al balance del Centenario, el diario incluye una noticia del director del Instituto Cervantes, César Antonio Molina, en noviembre de 2005, donde se muestra muy orgulloso de los actos organizados y critica a los que se quejan y «están hartos del Quijote», porque también hay quien está «hasta la coronilla de los partidos de fútbol» (La Voz de Galicia, 16/11/2005).

\section{Artículos de opinión}

La Voz de Galicia incluye trece artículos de opinión relacionados con el IV Centenario de la publicación de la primera parte del Quijote. Todos son columnas, no encontramos ninguna carta al director ni editoriales. Alfonso de la Vega y Ángel Padín son los colaboradores que más opinan en este tema, pues el primero escribe tres textos y el segundo, dos.

Alfonso de la Vega, el 4 de febrero de 2004, aprovecha que el presidente del Gobierno, José Luis Rodríguez Zapatero, quiere celebrar la efemérides el próximo año para darle consejos en clave quijotesca de cómo debe gobernar. En la siguiente columna, De la Vega considera lógico que Barcelona celebre 
los actos del Centenario, por la importancia de la ciudad en la novela, y critica que se haga en catalán.

Allí [en Barcelona], don Quijote visita una imprenta y teoriza sobre las dificultades de las traducciones, a las que compara con tapices vistos al revés; en consecuencia, esperemos que las lecturas se hagan en lengua española, sin ceder a los chantajes nacionalistas. ( La Voz de Galicia, Opinión, Garita de Herberia, 02/10/2004)

Nos resulta curioso que el columnista se muestre profundamente crítico con el nacionalismo catalán, cuando Galicia es también una nacionalidad histórica, si bien es cierto que con pretensiones políticas muy distintas a las de Cataluña. En cuanto a la reprobación de la lengua catalana como traducción del Quijote, también nos parece chocante, en un diario que publica algunos artículos en gallego. En su último artículo, del 1 de julio de 2005, De la Vega utiliza la efemérides para criticar el Gobierno de Zapatero.

Ángel Padín, periodista y escritor, por su parte, recuerda una exposición que organizó La Coruña hace unas décadas con 500 ejemplares de la obra y reivindica el origen gallego de Cervantes, algo que hasta el momento no ha sido probado ni escrito en ninguna obra de reconocido prestigio, y de dos de las frases de la gran novela. También apunta, en el texto del 27 de octubre de 2004, que la ciudad homenajeó al Quijote en su III Centenario. En el siguiente artículo, en marzo de 2005, Padín se muestra crítico con las autoridades de La Coruña por no haberse implicado en la celebración de la efemérides pero es optimista y espera que en breve se organicen diferentes actos.

La siguiente consideración es preguntar por qué nuestro Ayuntamiento no prepara algún acto para conmemorar este nuevo aniversario del Quijote. Ya lo hemos indicado en su día: en 1968 sí se celebró una exposición y varios actos. El concejal es ahora González Garcés (y con ese apellido) seguro que lo organizará. (La Voz de Galicia, La Coruña, Plaza Pública, 02/03/2005)

Cuando habla del apellido de González Garcés, Padín está haciendo referencia al poeta gallego Miguel González Garcés, que falleció en 1989. Por esa razón, porque el concejal lleva los mismos apellidos que el artista, Padín cree que organizará actos conmemorativos en La Coruña.

Otros artículos interesantes pertenecen al periodista César Casal y a un columnista escondido bajo el pseudónimo de Pablos. En el primero, de 2004, Casal defiende la celebración de la efemérides por el incalculable valor de la obra y, por encima de todo, su lectura.

400 años de número uno son muchos años. Se merece todas las reediciones, todos los estudios. Pero lo que más se merece es, lo que menos se hace, que lo lean. De pe a pa. A saltos. Como sea. (La Voz de Galicia, En tinta china, De locos, 18/10/2005) 
Pablos, por su parte, redacta un artículo donde apunta que Cervantes no tuvo ninguna relación con Galicia, una tesis que viene a contradecir la idea de muchos intelectuales gallegos, que circunscriben el nacimiento de la familia del escritor a tierras gallegas. Como hemos visto, La Voz de Galicia da cobertura a estas elucubraciones.

No es que Cervantes sea gallego, por mucha coincidencia que su apellido tenga con la localidad luguesa [...]. Documentado está que el padre del ilustre novelista era de origen andaluz, y que ninguna relación tuvo el famoso hijo con Galicia, salvo dedicar una de las partes de la novela al Conde de Lemos. (La Voz de Galicia, Vigo, Contrastes, 18/04/2005)

Como hemos visto, a pesar de los numerosos artículos de opinión publicados, ninguno de ellos valora en condiciones las actividades celebradas en Galicia. Tampoco hemos encontrado ningún texto con algo de profundidad, perteneciente a algún cervantista, que nos hablara con rigor de quién fue Cervantes y de la importancia del Quijote. Todos los artículos son sencillos y bastante superficiales, con lo que podemos afirmar que en La Voz de Galicia no se produce un verdadero debate intelectual respecto a la efemérides.

\section{HACIA UNAS CONCLUSIONES TEMÁTICAS}

Una vez que hemos estudiado en detalle cada diario, resulta conveniente realizar comparaciones entre los periódicos con el fin de extraer conclusiones que nos ayuden a conocer y entender cuál fue el papel de la prensa española en la celebración de la efemérides. Para ello, estudiaremos seis cuestiones generales básicas: ¿cómo fue la cobertura del evento?, ¿cuál fue el valor de los artículos de opinión publicados?, ¿se convirtió al Quijote en un símbolo nacionalista?, ¿se produjo un auténtico debate intelectual?, ¿se utilizó al hidalgo como un mero elemento comercial, tanto en los diarios como en las actividades promovidas por las autoridades?, y, por último, ¿generó mucha crispación en el terreno político?

\section{Cobertura de la efemérides}

Como hemos comprobado a lo largo de las páginas anteriores, los diarios analizados prestan una cobertura mayoritariamente informativa a la celebración del IV Centenario de la primera parte del Quijote, donde destaca la noticia como género predominante.

Por otro lado, es importante destacar que tanto El Mundo como El País, o, mejor dicho, Unidad Editorial y PRISA, se convirtieron en 2005 en patrocinadores de la efemérides, una de las causas de la más que aceptable cobertura que brindaron estos dos diarios generalistas a los eventos conmemorativos. 
En cuanto a las actividades a las que dan cobertura, los diarios tratan de recoger los principales eventos celebrados en toda España, aunque suelen pecar de centralismo y dan más relieve a los actos organizados en Madrid, a excepción de La Voz de Galicia y La Vanguardia, que se centran en Galicia y Barcelona, respectivamente. Los periódicos, además, se suelen hacer eco de los eventos que tienen lugar en el extranjero, tanto en el resto de Europa como en América del Sur.

Por otro lado, sólo dos diarios siguen los pasos de Azorín, que en 1905 recorrió la Ruta del Quijote por La Mancha y escribió crónicas sobre lo que vio en el diario El Imparcial. El escritor Andrés Trapiello, acompañado por el fotógrafo Juan Manuel Castro Pietro, redactó una excelente y emotiva crónica de viaje para el Magazine de La Vanguardia a finales de 2004 como preámbulo de lo que sería la efemérides del año siguiente. El periodista Antonio Lucas fue el enviado especial de El Mundo a Castilla-La Mancha en el verano de 2005. Lucas recorrió solo los principales pueblos manchegos reflejados en el libro y plasmó sus impresiones en ocho textos aderezados con pasajes del Quijote.

\section{Artículos de opinión}

En el primer escalón del género valorativo situamos a $A B C$, El País y El Mun$d o$, con veintisiete, veinticinco y dieciocho textos, respectivamente. Además de columnas de opinión, todos ellos incluyen cartas al director y editoriales ( $A B C$ no publica estos últimos) relacionados con la efemérides. La temática de los textos es variada, aunque, por ejemplo, en el caso de $A B C$, predominan los textos referentes al nacionalismo y las críticas al presidente del Gobierno, José Luis Rodríguez Zapatero.

El País y El Mundo publican artículos de todo tipo, algunos de ellos de ilustres escritores como José Saramago o Francisco Ayala, en el caso de $E l$ País, y Francisco Umbral o Luis Antonio de Villena, en El Mundo. En este último diario, son comunes los textos en contra de las actividades celebradas, como el de José Luis Jiménez o el de Santos Sanz de Villanueva. En El País, en cambio, encontramos artículos a favor, como un editorial o un texto de Andrés Trapiello, y en contra, de Manuel Llorís, Luis Manuel Ruiz, Margarita Rivière y Javier Maderuelo. A pesar de publicar estos últimos textos contrarios a las actividades conmemorativas del centenario, podemos afirmar que El País se posicionó a favor del IV Centenario, ya que así lo mostró en su editorial, algo lógico si tenemos en cuenta que PRISA fue uno de los patrocinadores de la efemérides. El Mundo, en cambio, no escribió ningún editorial a favor de las actividades celebradas.

En cuanto a La Vanguardia, de las cuatro columnas de opinión que recoge sobresalen dos, donde los articulistas aseguran que Barcelona es la ciudad española que más está celebrando la efemérides, una afirmación que, como 
hemos podido comprobar en las páginas anteriores, es completamente falsa. En La Voz de Galicia, con trece artículos de opinión, nos llama la atención un texto de Alfonso de la Vega, en el que pide a Barcelona que se implique en la efemérides, por el peso de la ciudad en la novela, y les ruega a los barceloneses que las lecturas del libro no las hagan en catalán.

\section{¿Un símbolo nacionalista?}

Cuando en 1905 se celebró el III Centenario de la publicación de la primera parte del Quijote, se utilizó la efemérides como un símbolo de unión de todos los españoles, para restaurar el sentimiento nacional, muy dañado tras las pérdidas de las colonias por el desastre del 98 . Cien años después, la realidad de España era completamente distinta. Estaba más que superada la pérdida de Cuba y Filipinas y el sentimiento nacional no era algo que estuviera de moda. Por esa razón, veremos cómo buena parte de los diarios pasa de puntillas por este tema o incluso lo ignora.

El País, La Vanguardia y La Voz de Galicia no incluyen ninguna información ni artículo de opinión reseñable donde se identifique al Quijote con un símbolo de la nación española o donde se critique esta identificación. En El País, por ejemplo, cobra más importancia el feminismo en la novela que el nacionalismo.

$A B C$ y El Mundo son los periódicos analizados que dan más relevancia a este tema. El segundo publica tres informaciones en las que aparecen el cervantista Francisco Rico, el historiador Ricardo García Cárcel y la escritora Carme Riera, donde los tres se muestran en contra de ver en la novela de Cervantes un símbolo de España. Rico considera que convertir el Quijote en un símbolo castizo es empequeñecerlo; García Cárcel, por su parte, cree que la épica de don Quijote nunca fue nacional, lo que explica que se identifiquen con el hidalgo las personas que representan a una tercera España alternativa, ni católica ni liberal; Riera, además, añade que los clásicos en el siglo XXI se leen como literatura y ya no se politizan.

En el diario $A B C$, en cambio, encontramos tres informaciones u artículos de opinión que defienden la idea del Quijote como aglutinante de la nación española, mientras que sólo aparece un argumento contrario, de nuevo de Carme Riera, que espera que se abandonen los clichés nacionalistas con la novela para sacarle el mayor provecho. El presidente de Castilla-La Mancha, José María Barreda, es uno de los pocos personajes públicos que continúa viendo en el hidalgo un símbolo nacionalista. Dos articulistas escriben en la línea de Barreda. En primer lugar, Teresa Sánchez-Vaquera indica que la novela es el símbolo más español y más universal de todos. Alonso de los Ríos, por su parte, opina que no tiene sentido que el Gobierno se involucre en la efemérides cuando no siente los colores del país, algo que también le ocurre, en su opinión, a la mayoría de los pensadores e intelectuales españoles. 
Vemos, por tanto, cómo el único diario que da importancia en sus páginas a la identificación del Quijote como un símbolo de la nación española es $A B C$. Para el resto, el nacionalismo en el libro es un tema completamente secundario.

\section{¿Debate intelectual?}

Resulta complicado juzgar si ha existido o no un debate intelectual alrededor de la novela. Las cientos de conferencias organizadas por toda España, tanto en universidades como en ateneos, bibliotecas, museos, ayuntamientos y asociaciones privadas pueden ser un ejemplo de debate intelectual. Sin embargo, establecer ese juicio se escapa al objetivo de esta investigación, que pretende estudiar lo que significó la efemérides a través del prisma de los principales diarios del país. Por esa razón, lo que debemos preguntarnos, y responder, es si efectivamente en la prensa se produjo un auténtico debate intelectual relativo a la obra.

Los diarios que han realizado una cobertura meramente informativa, con escasos artículos de opinión, podemos afirmar que no han propiciado ningún tipo de reflexión ni debate sobre la novela. Aquí situaríamos a $L a$ Vanguardia.

En otro anaquel tenemos a La Voz de Galicia. Este diario sí que incluye numerosos artículos de opinión, pero el contenido de los mismos provoca, de nuevo, la ausencia de un verdadero debate intelectual. Los artículos que incorpora el diario gallego carecen de la profundidad necesaria para incitar a la reflexión, no se muestran apenas críticos con las actividades organizadas, ni encontramos textos que nos permitan conocer mejor la novela o a su autor.

En las páginas de los tres mayores diarios generalistas de España $-E l$ País, El Mundo y $A B C$ - sí que pensamos que se produce un auténtico debate intelectual en torno a la novela gracias a la heterogeneidad de los artículos de opinión publicados. Consideramos que el diario El País es el que más incita a la reflexión de los tres, pues recoge textos de articulistas completamente a favor de las celebraciones del IV Centenario con otros que se muestran totalmente en contra. En el caso de $A B C$ y $E l M u n d o$, el primero se inclina demasiado hacia posturas nacionalistas y se posiciona completamente en contra de la actuación del presidente del Gobierno, mientras que en el segundo predomina el tono negativo frente a las actividades organizadas para la efemérides.

El País, además, y en eso coincide con El Mundo y $A B C$, incluye numerosos artículos donde desarrollan distintos temas clave de la obra, como la libertad o el valor, o nos recuerda quién fue Miguel de Cervantes. Por todo ello, pensamos que solo en estos tres diarios se lleva a cabo un verdadero debate intelectual en torno a la novela. 


\section{¿Un elemento comercial?}

El fin último de todo centenario de cualquier libro es que este y su autor o autora sean más conocidos y, sobre todo, que la obra sea más leída por la sociedad. Es la meta que debe perseguir cualquier actividad conmemorativa. Como hemos visto en las informaciones recogidas por los diarios analizados, esto no siempre ocurrió en los eventos celebrados en torno al Quijote. Encontramos numerosos espectáculos que lo único que buscaban era subirse al carro del Centenario para ganar dinero, y lo mismo con la publicación de libros, cómics y la puesta en escena de conciertos de grupos pop o rock que poco incitaban a la lectura de la novela.

En la prensa también se produjeron situaciones similares. Como hemos visto, el diario $A B C$ regaló en 2004 la universal novela en dos tomos, patrocinados por la Junta de Castilla-La Mancha. A cambio, el periódico publica dos publirreportajes especiales sobre la Ruta del Quijote y la comunidad manchega. Pocos meses después, $A B C$ venderá por 99 euros una edición de lujo de la obra ilustrada por el famoso grabador francés del siglo XIX Gustave Doré. En este punto, nos preguntamos si con esta iniciativa utilizan al Hidalgo con el fin de ganar dinero, mediante la venta de más ejemplares, o lo que realmente pretenden es fomentar la lectura del libro a través de la venta del mismo. Trataremos de ser neutrales y diremos que ambas cosas.

Por último, queremos referirnos al por aquel entonces presidente de la Generalitat, Pascual Maragall. Según manifestó en el Parlamento Catalán, Cataluña se estaba implicando en la celebración del IV Centenario del Quijote porque esperaban que cuando celebraran el Centenario de Tirant lo Blanc, el Gobierno central se volcase de la misma forma que ellos lo estaban haciendo en ese momento. Es decir, las exposiciones organizadas en Barcelona no buscaban un fomento de la lectura del libro y un mayor conocimiento de la novela y su autor: su verdadera meta era ser un arma arrojadiza en el futuro, algo que poder echar en cara dentro de unos años.

\section{¿Crispación política?}

Una efemérides de la relevancia del IV Centenario del Quijote tenía que causar críticas en el terreno político, y más teniendo en cuenta que el presidente del Gobierno, José Luis Rodríguez Zapatero, la utilizó como estandarte en la campaña electoral de las elecciones de marzo de 2004.

El diario $A B C$, por ejemplo, se muestra profundamente crítico con la ausencia del presidente del Gobierno en la presentación de los actos del IV Centenario el 20 de diciembre de 2004, tanto en las noticias que retratan el evento como en dos columnas de opinión. Además, se hace eco de la opinión del Partido Popular, que considera que Zapatero no ha acudido a la presentación porque las actividades no están a la talla de la efemérides. 
El Mundo, por su parte, también se muestra crítico con la ausencia de Zapatero en la presentación oficial de las actividades de la efemérides, aunque no tanto como $A B C$ (no recoge columnas de opinión al respecto, ni da tanta voz al Partido Popular).

En La Voz de Galicia las críticas vienen de la mano del PSOE de Ourense y del municipio de Teo (La Coruña). Los primeros piden a la Diputación que publique una edición en gallego de la novela, mientras que los segundos solicitan al Alcalde de la localidad, del Partido Popular, la celebración de algún evento conmemorativo que homenajee al castellano.

En La Vanguardia, aparece el por aquel entonces líder de Esquerra Republicana de Catalunya, Josep Lluís Carod-Rovira, que se lamenta ante Maragall del poco apoyo que está proporcionando la Generalitat al centenario de la novela Solitud de Víctor Catalá, en comparación con los actos del Quijote.

No en toda la prensa se generó la crispación política que acabamos de describir. Un diario de la talla de El País, por ejemplo, no recoge ni una sola crítica política contra el Centenario. Es por todos reconocida la proximidad del diario con el PSOE, lo cual explica sin duda esta ausencia de polémicas.

\section{BIBLIOGRAFÍA}

Ayuso, A., «La Ilustración Española y Americana ante el Tercer Centenario del Quijote», Espéculo. Revista de estudios literarios [en línea], 35, 2007, disponible en 〈http://www. ucm.es/info/especulo/numero35/tricente.html .

Azorín, La ruta de don Quijote, Madrid, Cátedra, Letras Hispánicas, 2005.

Becerra, P. y Sawa, M., Crónica del Centenario del don Quijote, Madrid, Establecimiento tipográfico de Antonio Marzo, 1905.

Bernat VistarinI, P., «Cuarto centenario del Quijote», Revista de libros, 101, 2005, pp. 33-35.

Betto, F., «La razón crítica de Cervantes y la locura de don Quijote», Revista de la Casa de las Américas, 239, 2005, pp. 97-99.

Canavaggio, J., Los baños de Argel, Madrid, Taurus, 1984.

Canavaggio, J., Entremeses, Madrid, Taurus, 1988.

Canavaggio, J., Don Quijote, del libro al mito, Madrid, Espasa Calpe, 2006.

De Maeztu, R., «Ante las fiestas del Quijote», Alma española, I, 13/12/1903.

Delgado IDARRETA, J. M., «La prensa: fuente historiográfica», en Investigación humanística y científica en La Rioja: homenaje a Julio Luis Fernández Sevilla y Mayela Balmaseda Aróspide, Logroño, Instituto de Estudios Riojanos, 2000, pp. 245-255.

ENCINAR, Á., «Don Quijote: una dialéctica entre la cordura y la locura», Anthropos, 17, 1989, pp. 233-238.

Falcón, L., Amor, sexo y aventura en las mujeres del Quijote, Madrid, Vindicación Feminista, 1997.

Flores Arroyuelo, F. J., 1905. Tercer Centenario del Quijote, Murcia, Nausícaä, 2006.

Gómez Pellón, E., «Recordando a Cervantes a propósito del cuarto centenario de la publicación del Quijote: la construcción social de la realidad como cuestión antropológica», Anales de la Fundación Joaquín Costa, 22-23, 2005-2006, pp. 121-144.

Goytisolo, L., «La locura de Don Quijote», Claves de razón práctica, 150, 2005, p. 61.

Iglesias FeiJoo, L., «En el centenario de Cervantes: el Quijote y la novela», en Campus stellae: haciendo camino en la investigación literaria, Dolores Fernández López, Mónica Domínguez Pérez y Fernando Rodríguez-Gallego (coords.), vol. 1, 2006, pp. 23-38. 
Johnson Carroll, B., «Cómo se lee hoy el Quijote», Cervantes, CEC-1995, pp. 335-348. La Vanguardia, Barcelona, 2004-2005.

LóPEZ RoldÁn, E., «De cómo se celebró el III Centenario del Quijote», Barcarola: revista de creación literaria, 65-66, 2005, pp. 273-278.

LÓPEZ VAREA, M. ${ }^{a}$ E., «El III Centenario del Quijote en la Universidad Española», en El Quijote en las bibliotecas universitarias españolas, Francisco Alía Miranda, Antonio L. Galán Gall y Ramón Rodríguez Álvarez (coords.), 2005, pp. 97-130.

Marín PinA, M. ${ }^{a}$ del C., "La aventura de leer y las mujeres del Quijote», Boletín de la Real Academia Española, tomo 85, cuadernos 291-292, 2005, pp. 417-441.

Márquez Villanueva, F., Fuentes literarias cervantinas, Madrid, Gredos, 1973.

Márquez VillanueVA, F., «La buenaventura de Preciosa», NRFH, 34, 1985-1986, pp. 741-768.

Márquez Villanueva, F., «Cervantes y el erotismo estudiantil», Ínsula, 538, 1991, pp. 26-28.

Miguel, J., "Cuarto centenario del Quijote: El Quixot a Barcelona», Revista de lenguas y literaturas catalana, gallega y vasca, 11, 2005, pp. 329-356.

Palomo, P., Movimientos literarios y periodismo en España, Madrid, Síntesis, 1997.

PÉREZ GARCíA, N., «El filo de un centenario: la crítica extravagante sobre el Quijote en 1916», Anales cervantinos, 33, 1995-1997, pp. 325-336.

RIERA, C., El Quijote desde el nacionalismo catalán, en torno al Tercer Centenario, Barcelona, Ediciones Destino, 2005.

Rivera, J., El Periodismo Cultural, Buenos Aires, Paidós, 1995.

SÁız, M. D. y Seonne, M. C., Cuatro siglos de periodismo en España. De los avisos a los periódicos digitales, Madrid, Alianza Editorial, 2007.

SATAKE, K., «En torno a Cardenio en el Quijote: Locura, suerte y honor», Anales cervantinos, 24, 1986, pp. 93-102.

STORM, E., «El tercer centenario del don Quijote en 1905 y el nacionalismo español», Hispania: revista española de historia, 199, 1998, pp. 625-654.

VeGA, P., «Chesterton y Maeztu ante la utopía quijotesca», Espéculo. Revista de estudios literarios [en línea], 38, 2008, disponible en 〈http:/www.ucm.es/info/especulo/numero38/ chesmaez.html.

Wiltrout, A. E., «Las mujeres del Quijote», Anales cervantinos, 12, 1973, pp. 167-172.

\section{HEMEROTECAS DIGITALES}

$-A B C$

〈http://www.abc.es/hemeroteca/resultados-busqueda/3/01012004/31122005/9/quijote.

html $)$

- El Mundo

〈http://ariadna.elmundo.es/buscador/archivo.html? $q=$ centenario\%20quijote\& $t=1 \& i=7$

$6 \& n=15 \& f d=01 / 01 / 2004 \& t d=01 / 01 / 2006 \& w=70 \& d=2 \& s=1$ >

- El País

〈http://www.elpais.com/todo-sobre/tema/IV/centenario/Quijote/134/〉

- La Voz de Galicia

〈http://www.lavozdegalicia.es/SSEE/buscavoz/resultados.jsp 


\title{
Resumen
}

En el presente estudio hemos analizado la cobertura que brindaron los principales periódicos españoles (El País, El Mundo, ABC, La Vanguardia y La Voz de Galicia) a las actividades organizadas con motivo del IV Centenario de la publicación de la primera parte de El ingenioso hidalgo Don Quijote de la Mancha, de Miguel de Cervantes, efemérides que tuvo lugar en 2005. Hemos estudiado informaciones de todo tipo de géneros periodísticos (noticias, reportajes, entrevistas, crónicas y artículos de opinión) con el fin de poder averiguar si en las páginas de estos periódicos se produjo un auténtico debate intelectual. Veremos también si se utilizó al famoso caballero como un simple elemento comercial y si su efemérides generó crispación política.

Palabras clave: Quijote. Cuarto centenario. Opinión pública. Prensa. El País. El Mundo. $A B C$.

Title: The Spanish press and $4^{\text {th }}$ centenary of the edition of the first part of Quixote (2005)

\begin{abstract}
In this work, we studied the Spanish press coverage (El País, El Mundo, ABC, La Vanguardia y La Voz de Galicia) with Fourth Centenary's activities of publication of first half of El ingenioso hidalgo Don Quijote de la Mancha, by Miguel de Cervantes, centenary celebrated in 2005. We analyzed all the kinds of information (news, reports, interviews and opinion articles) in order to find if there was an intellectual debate in these newspapers. Furthermore, we will study if the famous knight-errant was a commercial element and if his centenary caused political tension.
\end{abstract}

Key words: Quixote. Fourth Centenary. Public opinión. Press. El País. El Mundo. ABC. 